\title{
Tender Coconut Water Inhibits the Process of Lipid Peroxidation, Reduce Glucose Levels, and Increase Plasma Insulin in Pregnant Diabetic Rats
}

\author{
Friday Super Nova ${ }^{1}$, Shofa Chasani ${ }^{2}$, Atina Hussanna ${ }^{2}$, Siti Thomas Zulaikhah ${ }^{2, *}$
}

Friday Super Nova', Shofa

Chasani $^{2}$, Atina Hussanna ${ }^{2}$, Siti

Thomas Zulaikhah ${ }^{2, *}$

'Student Program Master of Biomedical Science Faculty of Medicine Sultan Agung Islamic University, INDONESIA.

${ }^{2}$ Lecturers Program Master of Biomedical Science Faculty of Medicine Sultan Agung Islamic University, INDONESIA.

\section{Correspondence}

Siti Thomas Zulaikhah

JI. Raya Kaligawe KM. 4 Semarang Central Java, INDONESIA

Phone no: 085727299463

E-mail: sitithomas@unissula.ac.id

History

- Submission Date: 12-10-2019;

- Review completed: 24-10-2019;

- Accepted Date: 07-11-2019.

DOI : 10.5530/pj.2020.12.24

Article Available online

http://www.phcogj.com/v12/i1

Copyright

(C) 2020 Phcogi.Com. This is an openaccess article distributed under the terms of the Creative Commons Attribution 4.0 International license.

\begin{abstract}
Background: Diabetes during pregnancy or Gestational Diabetes Mellitus (GDM) causes oxidative stress and have bad effect for mother and baby, risk of abortion, still birth, premature and preeclampsia. GDM can be prevented by monitoring the glucose level and providing rich antioxidants meals. TCW is a nutritious healthy drink rich in antioxidants, diet rich in antioxidants promotes better health, Inhibits lipid peroxidation and enhances the total antioxidant status. Aim and Objectives: This research to investigate the effect of tender coconut water can prevent lipid peroxidation, reduce glucose levels and increase insulin plasma level on pregnant diabetic rats. Material and Methods: Experimental study by post test only control group design, population of pregnant wistar strain rats. Twenty four samples used in this study were randomly divided into 4 groups, K1 (pregnant rats), K2 (pregnant rats+diabetic), K3 (pregnant rats+diabetic+ glibenklamid $0.23 \mathrm{mg} / \mathrm{kg} \mathrm{BW}$ ) and K4 (pregnant rats+diabetic+TCW $8 \mathrm{~mL} / 200 \mathrm{grBW}$ ). Diabetes Mellitus were induced using Streptozotocin (STZ) $65 \mathrm{mg} / \mathrm{kgBW}$ and Nicotinamid $230 \mathrm{mg} / \mathrm{kgBW}$. Data on insulin plasma, glucose and MDA levels were analyzed using One Way Anova with significant level 0.05. Result: The results showed that the average insulin plasma levels in group 2 decreased compared to group 1 , in group 3 and 4 it increased compared to group 2. Average glucose and MDA levels in group 2 increased compared to group 1 , in group 3 and 4 it decreased compared to group 2 . The results of the analysis has the $p$ values $0.000(p<0.05)$. Conclusion:TCW can inhibit the process of lipid peroxidation, reduce glucose levels, increase insulin plasma levels and in pregnant diabetic rats.

Key words: Tender coconut water (TCW), GDM, Lipid peroxidation, Insulin plasma, Glucose.
\end{abstract}

\section{INTRODUCTION}

Gestational Diabetes Mellitus (GDM) is described as glucose intolerance which diagnosed during pregnancy, this happens due to the increase of oxidative stress. Globally, one in 10 pregnancies can be related to diabetes, $90 \%$ among them are gestational diabetes (GDM). ${ }^{1}$ In 2015, almost 21 million births $(16,2 \%)$ were influenced by hyperglycemia during pregnancy. Among 85-90\% births of women with GDM, the $10 \%-15 \%$ rest of these pregnancies involved mothers with type 1 or type 2 diabetes or newly detected. in the United States prevalence of GDM increased by $56 \% .^{2}$ After the baby is born, usually GDM disappear. The Oral Glucose Tolerance Test (OGTT) were conducted for six weeks after delivery to make sure that the blood glucose is back to normal. However, the women with GDM have potential risk to get type 2 diabetes in the future include their offsprings and must be tested for diabetes at least once in every 2-3 years. ${ }^{1}$ Babies from GDM mothers have twice higher risk of injuries during delivery, three times possibility of caesarian delivery, and four times incidence to be admitted into Neonatal Intensive Care Unit (NICU). ${ }^{3}$

GDM happen if the body of a woman unable to produce sufficient insulin during her pregnancy.
Insulin is produced by the pancreas and help body cells to use glucose from blood as energy. Insulin deficiency can increase blood glucose. High level of blood glucose can cause problem to women and the babies if it is not maintained properly, have bad effect for mothers and babies, can risk to abortion, stillbirths, premature births, and pre eclampsia and also cause oxidative stress. ${ }^{4}$ Some micronutrients intake includes vitamin E, selenium and zinc are significantly low on women with GDM compared to heatlhy pregnant women, the selenium levels of GDM women also decreased, ${ }^{5}$ lack of selenium can decrease the activity of glutation peroxidase (GPx) to $90 \%$ so it cause lipid peroxidation. ${ }^{6}$ MDA levels as lipid peroxidation and oxidative stress biomarkers on women with GDM are higher compared to healthy pregnant women. ${ }^{5}$ The increased oxidative stress on GDM can cause the increase of free radicals and decrease of antioxidant protection ${ }^{7}$ Lipid peroxidation is significantly lowering the antioxidant capacity during the development of pregnancy. ${ }^{8}$

The prevention and management of GDM can be done by increasing the food consumption rich in antioxidant, fruit and vegetables and also other antioxidant rich sources. ${ }^{7}$ Tender coconut water is a natural, healthy, nutritious, provided by nature, easily obtained in tropical countries. Tender coconut

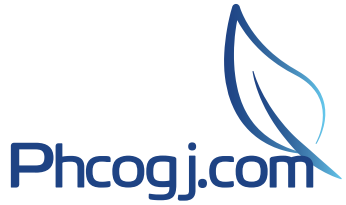

Cite this article: Nova FS, Chasani S, Hussanna A, Zulaikhah ST. Tender Coconut Water Inhibits the Process of Lipid Peroxidation, Reduce Glucose Levels, and Increase Plasma Insulin in Pregnant Diabetic Rats. Pharmacog J. 2020;12(1):162-7. 
water is rich in antioxidants, sources of free amino acid such as L-arginine, vitamin $\mathrm{C}$, selenium and minerals which can prevent lipid peroxidation. ${ }^{6}$ Several studies have proven that $\mathrm{L}$-arginine contained in tender coconut water is significantly can lower free radicals in the body. ${ }^{9}$ The antioxidant effect in coconut water can recover the sensitivity of insulin and has antihypertensive effect. ${ }^{10}$ Arginine also has the effect to regenerate pancreatic $\beta$ cells which cause activity from enzyme which regulates the carbohydrate metabolism and pancreatic damage back to normal. ${ }^{11}$ However, study on tender coconut water on oxidative stress on women with GDM is still limited. This research aims to prove that tender coconut water can prevent lipid peroxidation, lower glucose level and increase plasma insulin levels in pregnant diabetic rats.

\section{MATERIAL AND METHODS}

This study was designed as experiment research with Post-Test Control Group Design

\section{Ethical clearance}

This study received Ethical Clearance from the Bioethics Committee of Medical Research / Medical Faculty of Sultan Agung Islamic University, Semarang (No. 525/VIII/2019/Bioethics Commission).

\section{Tender coconut water}

TCW used was coconut varieties viridis (green coconut) aged 5-7 months and obtained from research surroundings. During the age of 5-7 months, coconut has tender, thin, jelly like endosperm and it is edible using spoon. The dosage administered is $8 \mathrm{ml} / 200 \mathrm{grBW} /$ day for 2 weeks.

\section{Experimental animal}

\section{Streptozotocin (STZ) dan Nicotinamide (NA)Induction}

Rats were adapted for 7 days with the surroundings, intraperitoneally induced by STZ dosage $65 \mathrm{mg} / \mathrm{kgBW}$ and nicotinamide $230 \mathrm{mg} / \mathrm{kgBW},{ }^{12}$ wait for 3 days then assessed for glucose level using glucometer, if the glucose level $>200 \mathrm{mg} / \mathrm{dL}$ rats can be used as research material. Dosage of the drug glibenclamide used $0,23 \mathrm{mg} / \mathrm{kgBW} .{ }^{13}$

\section{Administration procedures}

Rats used are pregnant wistar strain rats according to the criteria which are aged 2 months old, weighed approximately 180-220g, healthy appearance, active movement, normally fed, no wound and no defects. Of 24 rats were randomly divided into 4 groups and each group consists of 6 rats.

\begin{tabular}{|l|l|}
\hline Group 1 (K1): & $\begin{array}{l}\text { Pregnant wistar strain rat received standard feeding diet }+ \text { et } \\
\text { libitum drink }\end{array}$ \\
\hline Group 2 (K2): & $\begin{array}{l}\text { Pregnant wistar strain rat received standard feeding diet }+ \text { et } \\
\text { libitum drink and induced with STZ dose } 65 \mathrm{mg} / \mathrm{KgBW} \text { and } \\
\text { Nicotinamide dosis } 230 \mathrm{mg} / \mathrm{KgBW}\end{array}$ \\
\hline Group 3 (K3): & $\begin{array}{l}\text { Pregnant wistar strain rat received standard feeding diet }+ \text { et } \\
\text { libitum drink and induced with STZ dose } 65 \mathrm{mg} / \mathrm{KgBW} \text { and } \\
\text { Nicotinamide dosis } 230 \mathrm{mg} / \mathrm{KgBW} \text { and glibenclamide } 0,23 \mathrm{mg} / \\
\text { kgBW for } 2 \text { weeks. }\end{array}$ \\
\hline Group 4 (K4): & $\begin{array}{l}\text { Pregnant wistar strain rat received standard feeding diet }+ \text { et } \\
\text { libitum drink and induced with STZ dose } 65 \mathrm{mg} / \mathrm{KgBW} \text { and } \\
\text { Nicotinamide dosis } 230 \mathrm{mg} / \mathrm{KgBW} \text { also administering tender } \\
\text { coconut water dose } 8 \mathrm{~mL} / 200 \mathrm{grBW} \text { for } 2 \text { weeks. }\end{array}$ \\
\hline
\end{tabular}

After 2 weeks blood were drawn to measure glucose, plasma insulin and MDA level (Chart 1).

\section{Blood drawing procedure}

The equipment used is sterile microhematrocrit tubes, blood vials, and sterile cottons. Blood is taken by inserting a microhematocrit tube in the ophthalmic vein in the corner of the rats' eyes' periorbita then slowly rotated until the blood comes out. Blood coming out is contained in ependrof as much as $2 \mathrm{cc}$. Plug out the micro hematocrit tube if the required blood is sufficient, clean the remaining blood in the corner of the rat's eye using sterile cotton ${ }^{14}$. The examination of glucose levels, insulin plasma and MDA levels using ELISA method

\section{Research location}

The treatment of experimental animal and examination of MDA, glucose and insulin plasma levels was carried out in PAU Gadjah Mada University Yogyakarta.

\section{Statistical analysis}

The data from results of glucose levels, plasma insulin and MDA were tested for normality using Shapiro-Wilk and tested for homogeneity using Levene's Test. Data were normally distributed and homogenous therefore One way Anova continued with Post Hoc LSD test to determine the difference amongst groups. The determination of analysis is according to alpha $5 \% .^{15}$

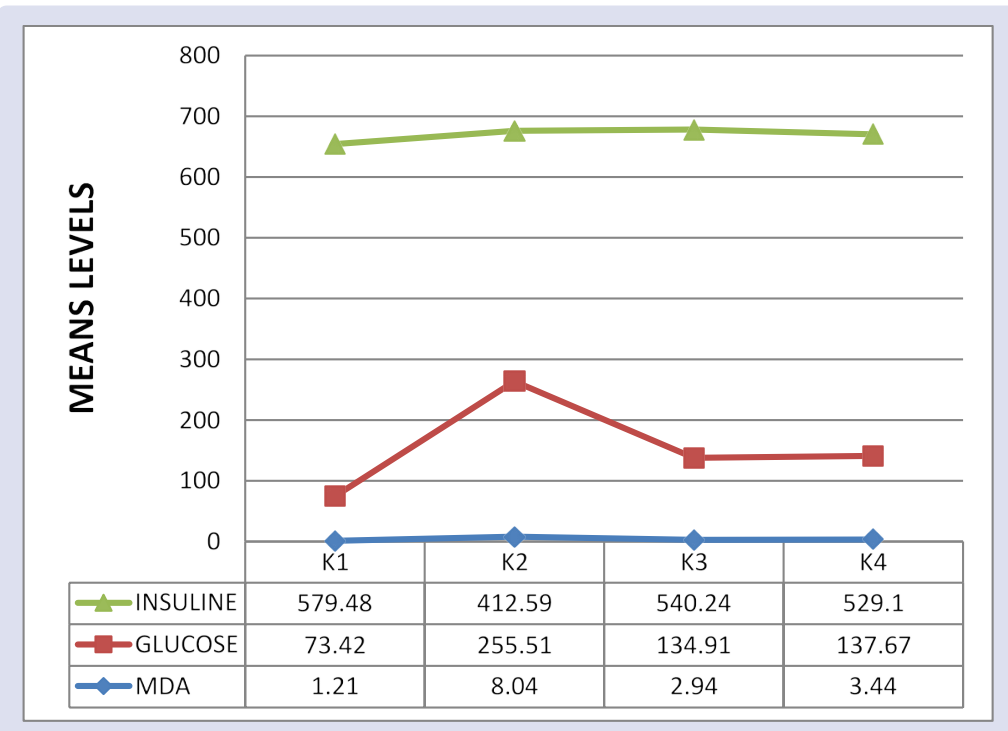

Chart 1: The average of plasma insulin, glucose, and MDA levels between groups, where $\mathrm{K} 1$ : control, $\mathrm{K} 2$ : DM, K3: DM+Glibenclamide, K4: DM + TCW. 


\section{RESULT}

Tender coconut water to Glucose level, insulin plasma and MDA levels mean are illustrated on Table 1.

Table 1 indicated that group K2 have highest mean of glucose level $(255.51 \pm 1.69 \mathrm{mg} / \mathrm{dL})$ while $\mathrm{K} 1$ is the lowest $(73.42 \pm 1.16 \mathrm{mg} / \mathrm{dL}), \mathrm{K} 3$ and $\mathrm{K} 4$ showed the lower mean $(134.91 \pm 4.95 \mathrm{mg} / \mathrm{dL}$ and $137.67 \pm 4.17$ $\mathrm{mg} / \mathrm{dL}$ ) compared to K2 but higher compared to K1, the mean decrease amount of glucose level between $\mathrm{K} 2$ and $\mathrm{K} 3=120.6 \mathrm{mg} / \mathrm{dL}$, between $\mathrm{K} 2$ dan $\mathrm{K} 4=117.84 \mathrm{mg} / \mathrm{dL}$. The lowest mean of plasma insulin in group $\mathrm{K} 2(412.59 \pm 3.19 \mathrm{pg} / \mathrm{mL})$ while $\mathrm{K} 1$ is the highest $(579.48 \pm 4.32 \mathrm{pg} /$ $\mathrm{mL}), \mathrm{K} 3$ and $\mathrm{K} 4$ showed higher mean levels $(540.24 \pm 3.13 \mathrm{pg} / \mathrm{mL}$ and $529.10 \pm 5.90 \mathrm{pg} / \mathrm{mL}$ ) compared to $\mathrm{K} 2$ but lower compared to $\mathrm{K} 1$, the mean increased amount of insulin level between $\mathrm{K} 2$ and $\mathrm{K} 3=127.65 \mathrm{pg} /$ $\mathrm{mL}$, between $\mathrm{K} 2$ and $\mathrm{K} 4=116.53 \mathrm{pg} / \mathrm{mL}$. The highest mean for MDA level on $\mathrm{K} 2(8,04 \pm 0.20 \mathrm{nmol} / \mathrm{mL})$ while the lowest is $\mathrm{K} 1(1.21 \pm 0.11$ $\mathrm{nmol} / \mathrm{mL}), \mathrm{K} 3$ and $\mathrm{K} 4$ showed lower means $(2.94 \pm 0.29 \mathrm{nmol} / \mathrm{mL}$ and $3.44 \pm 0.24 \mathrm{nmol} / \mathrm{mL}$ ) compared to $\mathrm{K} 2$ but higher compared to K1, the mean decrease amount of MDA levels between $\mathrm{K} 2$ and $\mathrm{K} 3=5.14 \mathrm{nmol} /$ $\mathrm{mL}$,between $\mathrm{K} 2$ and $\mathrm{K} 4=4.6 \mathrm{nmol} / \mathrm{mL}$. Analysis by Anova indicated that administration of tender coconut water dose $8 \mathrm{~mL} / 200 \mathrm{gBW} /$ day for 2 weeks can lower the glucose and MDA levels also increasing the plasma insulin $(\mathrm{p}<0.05)$. The decrease means for glucose and MDA levels by glibenclamide (K3) was lowest compared to the tender coconut water (K4). The increase of plasma insulin levels by glibenclamide (K3) was higher compared to tender coconut water (K4).

\section{DISCUSSION}

The result of study indicated that administration of tender coconut water dose $8 \mathrm{~mL} / 200 \mathrm{grBW}$ for 2 weeks is proven to lower the glucose levels, increasing plasma insulin level and preventing lipid peroxidation marked by the decreased of MDA levels in pregnant diabetic rats. This study was using pregnant rats induced by STZ and Na so rats become diabetic. The pathogenesis mechanism of DM is due to insulin resistance and $\beta$ cell dysfunction, to get diabetic condition in wistar strain rats, it is by injecting STZ and Na combinations, this was conducted for hyperglycemic and insulin resistance to occur as well as pancreatic damage. Glucose levels before and after STZ+Na were measured, increase of blood glucose after STZ+Na become indication of DM if the blood glucose is $>200 \mathrm{mg} / \mathrm{dL} .{ }^{16} \mathrm{STZ}$ induction resulted in toxic effect of pancreatic cell $\beta$ selectively and cause diabetic condition, have interconnections with glucose parts in its chemical structrure which allows STZ to enter pancreatic cell $\beta$ through Glucose transporter type 2 (GLUT-2) in plasmic membrane, pancreatic cell $\beta$ induced by
STZ caused the cell $\beta$ apoptosis. There are three main pathways to cell apoptosis which are: (1). DNA methylation through ion carbonium formation $\left(\mathrm{CH}^{3+}\right)$ can cause activation from poly ADP-ribosesynthase enzyme as part of the cellular repairing mechanism and as result, there is decrease of Nicotinamide Adenid Dinukeotida $\left(\mathrm{NAD}^{+}\right)$; (2). NO Production; (3). ROS Production in free radicals. ${ }^{17}$ The increase of oxidative stress causes diabetic problems. ${ }^{1}$

Oxidative stress is due to the imbalances between antioxidant defense system with free radicals due to the ROS increase and caused hyperglycemia. ${ }^{18}$ Oxidative stress has been recently recognized as a key mechanism in insulin resistance ${ }^{17}$. Some of the mechanisms of reaction which are considered to be involved in oxidative stress Genesis are auto-oxidation glucose, protein glycation, formation of advanced glycation products and polyol pathway. The involvement of ROS during STZ metabolism is the production of uric acid as a final product of ATP degradation by xanthine oxidase of hypoxanthine. This reaction will result in radical superoxidants and hydroxyl derived from dismutase $\mathrm{H}_{2} \mathrm{O}_{2}$ during hypoxanthine metabolism, which will accelerate the process of destruction of pancreatic cells $\beta$. Hydrogen peroxide $\left(\mathrm{H}_{2} \mathrm{O}_{2}\right)$ then produces free radicals such as superoxide anion $\left(\mathrm{O}_{2}^{-}\right)$and radical Hydroxil $\left(\mathrm{OH}^{-}\right)$. This reactive compound can lead to lipid peroxidation, resulting in the formation of hydroperotic and endotoxcide fatty acids. ${ }^{17}$ Research in this area has revealed that there is a strong correlation between the state of oxidative stress in the body and the incidence of insulin resistance and even late stage diabetes cases. ${ }^{19}$ Hyperglycemia can also induce pancreatic $\beta$-cell dysfunction, reduced $\beta$-cell mass, and insulin deficiency. ${ }^{16}$ Oxidative stress can be triggered due to elevated levels of glucose and increased free fatty acids (FFA) which causes increased ROS in the mitochondria, which eventually cause insulin resistance and $\beta$ cell dysfunction. ${ }^{18}$ The occurrence of insulin resistance and $\beta$ cell dysfunction can be seen in Figure 1 .

The use of L-arginine is increased in pregnant woman, this is due to an increased formation of nitric oxide, supporting adaptive vasodilation of pregnancy, and the use of L-arginine by the fetus. L-arginine supplementation in foods can provide substrate sources for nitric oxide synthesis during pregnancy. ${ }^{20} \mathrm{GDM}$ is associated with serious complications for both the mother and child, adverse consequences on the foetus and the mother increase linearly with increasing maternal blood glucose. ${ }^{1}$ GDM represents a defect in pancreatic $\beta$-cell function both during and after pregnancy and thus identifies a state of chronic $\beta$ cell dysfunction, rather than the mere development of relative insulin deficiency in the face of rising insulin resistance during pregnancy. ${ }^{1}$ Increased FFA levels have a positive correlation with insulin resistance and insulin resistance causing impaired glucose tolerance. ${ }^{18}$ Some

Table 1: The effect of tender coconut water on glucose level, insulin plasma and MDA level on 4 groups means.

\begin{tabular}{|c|c|c|c|c|c|}
\hline \multirow{3}{*}{ VARIABLE } & \multicolumn{4}{|c|}{ KELOMPOK } & \multirow{3}{*}{$\mathrm{p}$-value } \\
\hline & K1 & K2 & K3 & K4 & \\
\hline & Mean \pm SD & Mean $\pm S D$ & Mean \pm SD & Mean $\pm S D$ & \\
\hline \multirow{2}{*}{$\begin{array}{l}\text { Glucose level }(\mathrm{mg} / \mathrm{dL}) \\
\text { Shapiro wilk } \\
\text { Levene's test } \\
\text { One way Anova }\end{array}$} & $73.42 \pm 1.16$ & $255.51 \pm 1.69$ & $134.91 \pm 4.95$ & $137.67 \pm 4.17$ & \\
\hline & 0.911 & 0.999 & 0.265 & 0.573 & $\begin{array}{c}>0.05^{*} \\
>0.05^{* *} \\
0.0001^{* * *}\end{array}$ \\
\hline $\begin{array}{l}\text { Plasma insulin level }(\mathrm{mg} / \mathrm{mL}) \\
\text { Shapiro wilk }\end{array}$ & $579.48 \pm 4.32$ & $412.59 \pm 3.19$ & $540.24 \pm 3.13$ & $529.10 \pm 5.90$ & \\
\hline $\begin{array}{l}\text { Levene's test } \\
\text { One way Anova }\end{array}$ & 0.846 & 0.901 & 0.806 & 0.872 & $\begin{array}{c}>0.05^{\star} \\
>0.05^{\star *} \\
0.0001^{\star * *}\end{array}$ \\
\hline $\begin{array}{l}\text { MDA levels (nmol/mL) } \\
\text { Shapiro wilk }\end{array}$ & $1.21 \pm 0.11$ & $8.04 \pm 0.20$ & $2.94 \pm 0,29$ & $3.44 \pm 0,24$ & \\
\hline $\begin{array}{l}\text { Levene's test } \\
\text { One way Anova }\end{array}$ & 0.967 & 0.516 & 0.668 & 0.951 & $\begin{array}{l}>0.05^{* *} \\
0.0001^{* * *}\end{array}$ \\
\hline
\end{tabular}

Significant ${ }^{*}>0.05$ (Shapiro wilk), ${ }^{* *}>0.05$ (Levene ${ }^{*}$ est), ${ }^{* * *}<0.05$ (One way Anova) 


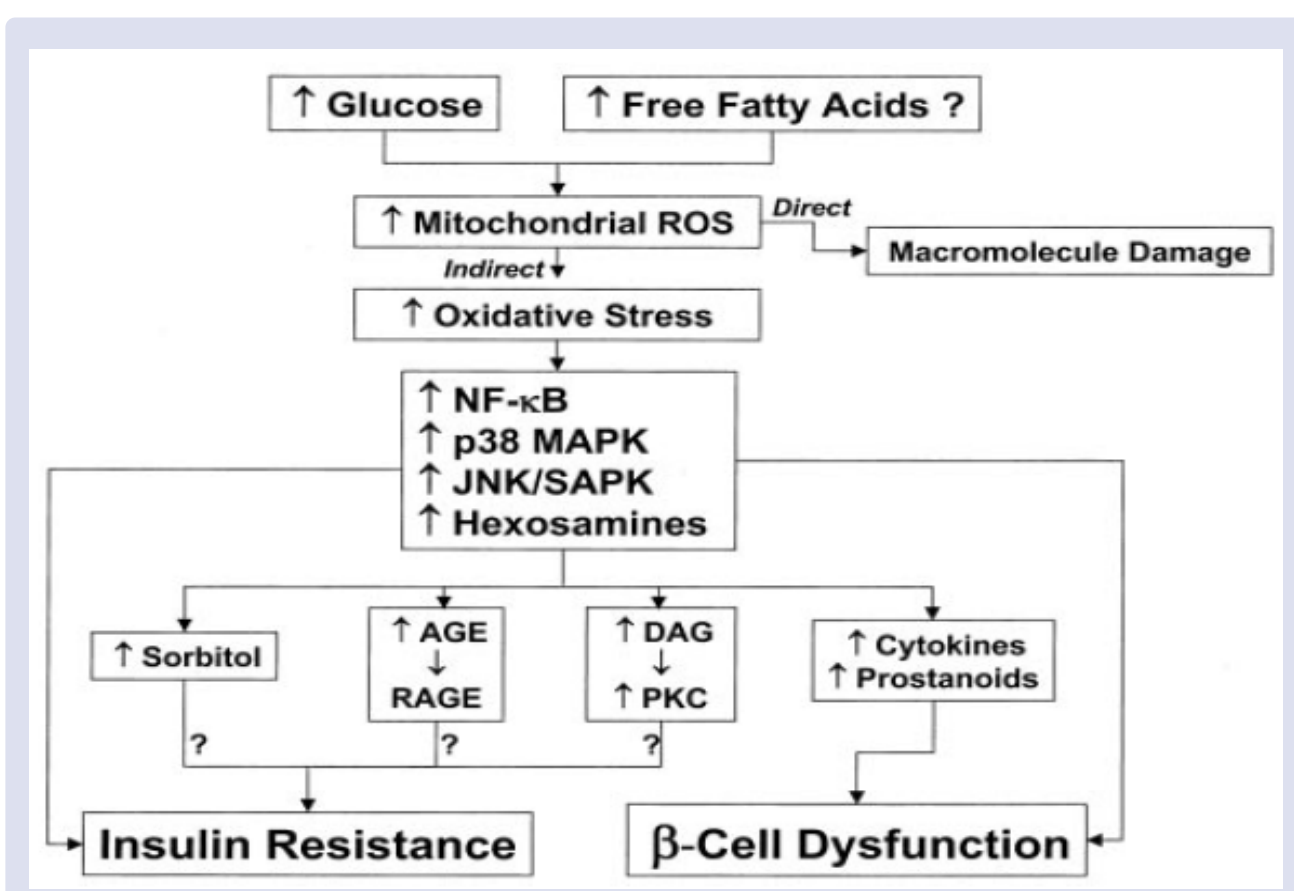

Figure 1: Insulin resistance and $\beta$ cell dysfunction due to high levels of glucose and FFA. ${ }^{18}$

clinical trials, suggesting that treatment with vitamin E, vitamin C, or glutathione (GSH) may increase insulin sensitivity in individuals who are resistant to insulin and or type- 2 diabetes mellitus patients.. ${ }^{7}$ In normal pregnancy and GDM, lipid transfer from mother to fetal blood passes the placenta through the process, which is regulated by insulin level. ${ }^{7}$ There is associations of environmental toxic/nutrient elements' exposure with GDM prevalence. ${ }^{21}$ For example, the exposure to arsenic and cadmium during pregnancy were significantly associated with GDM. $^{22}$

This research proved that young coconut water can prevent lipid peroxidation which is characterized by decreased MDA levels, this result in accordance with the research of Zulaikhah et al, stating that young coconut water is able to lower MDA levels of gold miners exposed to mercury. ${ }^{6}$ Human body put in place several strategies to counteract the effects of free radicals and oxidative stress, based on enzymatic (e.g., SOD, CAT, and GPx) and nonenzymatic (e.g., lipoic acid, glutathione, L-arginine, and coenzyme Q10) antioxidant molecules, all of them being endogenous antioxidants. Beside these, there are several exogenous antioxidant molecules of animal or vegetal origin, mainly introduced by diet or by nutritional supplementation. ${ }^{23}$ The lipid peroxidation process can be inhibited by compounds contained in young coconut water. L-arginine content contained in coconut water can be used as source no and no proved to be able to lower $\mathrm{Fe}$ and $\mathrm{Cu}$, so as to inhibit Fenton reaction and inhibit the formation of hydroxyl radicals $\left(\mathrm{OH}^{-}\right)$ which will eventually inhibits lipid peroxidation. ${ }^{24}$ The role of vitamin $\mathrm{C}$ works synergized with vitamin $\mathrm{E}$ in inhibiting lipid peroxidation process. Vitamin $\mathrm{E}$ which is oxidized by free radicals can react with vitamin $\mathrm{C}$, after getting a hydrogen ion from vitamin $\mathrm{C}$ will turn into vitamin $\mathrm{E}$. Vitamin $\mathrm{E}$ in the membrane reacts with radical lipids (LOO*) forms a radical vitamin $\mathrm{E}$ (Vit. $\mathrm{E}^{*}$ ). The radical vitamin $\mathrm{E}$ reacts with vitamin $\mathrm{C}$ to form free radicals vitamin $\mathrm{C}$ (Vit. $\mathrm{C}^{*}$ ). Radical vitamin $\mathrm{C}$ (Vit. $\mathrm{C}^{*}$ ) will experience regeneration into vitamin $\mathrm{C}$ by involving glutathione (GSH). GSH will be oxidized to oxidized glutathione (GSSG) by the enzyme glutathione peroxidase (GPx), GSSG will be rereduced to form GSH by the glutathione reduktese enzyme (Grade) by involving NADPH as an electron donor. ${ }^{25}$ Vitamin E ( $\alpha$-tocopherol) is a lipid-soluble vitamin which acts as a lipid peroxyl radical scavenger, preventing lipid peroxidation chain reactions in the cell membranes. ${ }^{26}$
Arginine supplementation has been shown to be a promising method of improving cardiovascular function type II diabetes by increasing endothelial NO synthesis. ${ }^{11}$ Tender coconut water contains L-arginine. ${ }^{27}$ L-arginine novel nutritional strategy, ${ }^{11}$ is non essential amino acid, in nitrid oxid synthetase (no synthase). This compound is kind substrates producing citrulline and NO. NO can inhibit xantin oxidase (XO), increase the levels of SOD, total levels of group (T-SH), vitamin C, total antioxidants (TAC) and inhibit free radical chain reactions through lipid peroxidation. ${ }^{6}$ One of the processes of superoxide formation in the body is through the xanthine or hypoxantin oxidation catalyzed by the xanthine oxidase $(\mathrm{XO})$ producing uric acid and superoxide, so that when $\mathrm{XO}$ is inhibited by L-Arginine's work then the production of superoxide Decreased due to the need of SOD to elaborate superoxide $\left(\mathrm{O}_{2}^{*}\right)$ to $\mathrm{H}_{2} \mathrm{O}_{2}$ also decreased and eventually hindered lipid peroxidation. ${ }^{6} \mathrm{~L}$-arginine as a precursor to nitric oxide (NO), may increase insulin secretion and reduce hyperglycemia, and this beneficial action is associated with increased formation of NO in diabetic patients. ${ }^{11}$

Glucose levels in this study also decreased after given young coconut water in diabetic pregnant rats. Young coconut water can be used as a source of mineral such as $\mathrm{Cu}, \mathrm{Zn}, \mathrm{Mn}, \mathrm{Mg}$ that is beneficial to the body ${ }^{27}$ Epidemiological studies show that most diabetics have low $\mathrm{Mg}$ levels. Insulin and glucose are important compounds in the metabolism of Mg. Low Intracellular Mg levels will lead to damaged kinase tyrosine activity, post-receptorial decline in insulin work, and worsening of insulin resistance in diabetic patients. Low $\mathrm{Mg}$ intake is associated with the development of type $2 \mathrm{DM}$. The deficiency of $\mathrm{Mg}$ can trigger the development of proinflammatory which causes production and excessive release of interleukin. $\mathrm{Mg}$ supplementation is a public health strategy to reduce the risk of diabetes. A prospective study of 85.000 women who are followed for 18 months are representing that women who consume the highest $\mathrm{mg}$ have a protective factor against type $2 \mathrm{DM}$ when compared to women who consume the lowest $\mathrm{Mg}(\mathrm{RR}=0.68) .{ }^{28}$ Results showed that mean levels of $\mathrm{Mg}$ serum with DM sufferers lower if compared with non DM (patients with $\mathrm{DM}=1.88 \pm 0.28 \mathrm{mg} / \mathrm{dL}$ and non $\mathrm{DM}=2.10 \pm 0.29 \mathrm{mg} / \mathrm{dL}$ ). There are differences in the significance of the mean $\mathrm{Mg}$ serum between patients with DM and non DM ( $P$ $<0.003) .{ }^{29}$ The effectiveness of the antioxidant enzyme SOD can be increased by the presence of minerals such as copper $(\mathrm{CU})$ and zinc 
$(\mathrm{Zn})$ and manganese (Mn). Lacks of minerals such as $\mathrm{Cu}, \mathrm{Zn}$ and $\mathrm{Mn}$ can decrease the activity of $\mathrm{Cu}-\mathrm{Zn}$ SOD and MN-SOD. SOD so that it can cause lipid peroxidation. ${ }^{6}$

\section{CONCLUSION}

Tender coconut water is able to inhibit the proces of lipid peroxidation, reduse glucose levels and increasing plasma insulin levels in pregnant diabetic wistar strain rats.

\section{ACKNOWLEDGEMENT}

This research was financed by Kemenristekdikti (DRPM) Republic of Indonesia with contract number: No. 112/SP2H/LT/DRPM/2019 and 201/B.1/SA-LPPM/V/2019.

\section{CONFLICTS OF INTEREST}

The authors declare that they have no conflicts of interest.

\section{ABBREVIATION}

TCW: Tender Coconut Water; GDM: Gestational diabetes mellitus ; MDA: Malondialdehyde; STZ: Streptozotocin, Na: Nicotinamid; DM: Diabetes mellitus; Glut-2: Glucose transporter type 2; DNA: Deoxyribonucleic acid; ADP: Adenosine diphosphate; ROS: Reactive Oxygen Species, OGTT: Oral Glucose Tolerance Test; NAD: Nicotinamide Adenid Dinukeotida ; PUFA: Poly Unsaturated Fatty Acid; XO: xanthine oxidase; NO: nitrat oksida; FFA: Free Faty Acid; GSH: Glutation; GSSG: Glutation Teroksidasi; GPx: Glutation peroksidasi; $\mathbf{H}_{2} \mathbf{O}_{2}$ : Hidrogen Peroksida; $\mathrm{O}_{2}^{-}:$Superoxide Anion; $\mathbf{O H}^{-}$: Radical Hidroxil; LOO: Radikal Lipid; NICU: Neonatal Intensive Care Unit; Cu: cuprum; Zn: Zing; Mn: mangan, Mg: Magnesium.

\section{REFERENCES}

1. Veerasamy $S$, Kapur A, Balaji $V$, Divakar $H$. A perspective on testing for gestational diabetes mellitus. Indian J Endocrinol Metab. 2015;19(4):529-32.

2. Ross GP, Falhammar $H$, Chen R, Barraclough $H$, Kleivenes $O$, Gallen I. Relationship between depression and diabetes in pregnancy: A systematic review. World J Diabetes. 2016;7(19):554.

3. Thomas R Moore, MD; Chief Editor: George T Griffing M more. Diabetes Mellitus and Pregnancy. Medscape. 2018.

4. $\mathrm{MOH}$. CPG Management of Diabetes in Pregnancy. 2017;38:70

5. Parast VM, Paknahad Z. Antioxidant Status and Risk of Gestational Diabetes Mellitus: a Case-Control Study. Clinical Nutrition Research. 2017;6(2):81.

6. Zulaikhah ST, Anies, Ari SS. Effects of Tender Coconut Water on Antioxidant Enzymatic Superoxida Dismutase ( SOD ), CATALASE ( CAT ), Glutathione Peroxidase ( GPx ) and Lipid Peroxidation In Mercury Exposure Workers. Int J Sci Res. 2015:4(12):517-24.

7. Sobrevia L, Salsoso R, Fuenzalida B, Barros E, Toledo L, Silva L, et al. Insulin is a key modulator of fetoplacental endothelium metabolic disturbances in gestational diabetes mellitus. Front Physiol. 2016;7:1-15.

8. Suhail M, Patil S, Khan S, Siddiqui S. Antioxidant vitamins and lipoperoxidation in non-pregnant, pregnant, and gestational diabetic women: erythrocytes osmotic fragility profiles. J Clin Med Res. 2010;2:266-73

9. Debmandal M, Mandal S. Coconut ( Cocos nucifera L .: Arecaceae ): In health promotion and disease prevention. Asian Pac J Trop Med. 2011;4(3):241-7.
10. Mohamad NE, Yeap SK, Ky H, Ho WY, Boo Y, Chua J, et al. Dietary coconut water vinegar for improvement of obesity-associated inflammation in high-fatdiet- treated mice. Food Nutr Res. 2017;61(1).

11. Preetha PP, Devi VG, Rajamohan T. Mature coconut water exhibits antidiabetic and antithrombotic potential via L-arginine-nitric oxide pathway in alloxan induced diabetic rats. J Basic Clin Physiol Pharmacol. 2015;26(6):575-83

12. Szkudelski T. Streptozotocin-nicotinamide-induced diabetes in the rat Characteristics of the experimental model. Exp Biol Med. 2012;237(5):481-90.

13. Candasamy M, Murthy TEK, Gubiyappa K, Chellappan D, Gupta G. Alteration of glucose lowering effect of glibenclamide on single and multiple treatments with fenofibrate in experimental rats and rabbit models. J Basic Clin Pharm. 2014;5(3):62.

14. Zulaikhah ST, Joko WW, Aziz RD, Dede RP, Ahmad FN. Effect of tender coconut water to prevent Anemia on Wistar Rats Induced by Lead (Plumbum) 2019;11(6):1325-30.

15. Dahlan MS. Pintu Gerbang Memahami Epidemiologi, Biostatik dan Metodologi Penelitian. Jakarta: epidemiologi Indonesia, 2018.

16. Qinna NA, Badwan AA. Impact of streptozotocin on altering normal glucose homeostasis during insulin testing in diabetic rats compared to normoglycemic rats. Drug Des Devel Ther. 2015;9:2515-25.

17. Eleazu CO, Eleazu KC, Chukwuma S, Essien UN. Review of the mechanism of cell death resulting from streptozotocin challenge in experimental animals, its practical use and potential risk to humans. 2013;1-7.

18. Evans JL, Ira D. Goldfine, Betty A. Maddux GMG. Perspectives in diabetes. Are Oxidative Stress?Activated Signaling Pathways Mediators of Insulin Resistance and ?-Cell Dysfunction? J Natl Med Assoc. 2003;52:476-8.

19. Hurrle S, Hsu WH. The etiology of oxidative stress in insulin resistance. Biomed J. 2017;40(5):257-62

20. Vadillo-Ortega F, Perichart-Perera O, Espino S, Avila-Vergara MA Ibarra Ahued $\mathrm{R}$, et al. Effect of supplementation during pregnancy with I-arginine and antioxidant vitamins in medical food on preeclampsia in high-risk population: Randomized controlled trial. Obstet Gynecol Surv. 2011:66(9):537-9.

21. Liu X, Zhang L, Li J, Meng G, Chi M, Li T, et al. A nested casecontrol study of the association between exposure to polybrominated diphenyl ethers and the risk of gestational diabetes mellitus. Environ. Int. 2018;119:232-8.

22. Wu Y, Zhang J, Peng S, Wang X, Luo L, Liu L, et al. Multiple elements related to metabolic markers in the context of gestational diabetes mellitus in meconium. Environ Int. 2018:121:1227-34.

23. Pizzino G, Irrera N, Cucinotta M, Pallio G, Mannino F, Arcoraci V, et al. Oxidative Stress: Harms and Benefits for Human Health. Oxid Med Cell Longev. 2017;2017.

24. Suliburska J, Bogdanski P, Krejpcio Z, Musialik DP, Jablecka A. The Effect of L-Arginine, Alone and Combined with Vitamin C, on Mineral Status in relation to its Antidiabetic, Anti-Inflamatory, and Antioxidant Properties in Male Rate on a High-Fat Diet. Biol Trace Elem Res. 2014;157(1):67-74

25. Zulaikhah ST, Sampurna S. Tender coconut water to prevent oxidative stress due to mercury exposure. IOSR J Environ Sci Toxicol Food Technol. 2016;10(6):35-8.

26. Katerji M, Filippova M, Duerksen-Hughes P. Approaches and methods to measure oxidative stress in clinical samples: Research applications in the cancer field. Oxid Med Cell Longev. 2019;2019.

27. Zulaikhah ST. Health benefits of tender coconut water (TCW). Int J Pharm Sc Res. 2019;10(2):474-80

28. Barbagallo M, Dominguez LJ. Diabetes and Clinical Research Magnesium and Type 2 Diabetes: An Update ClinMed. Int J Diabetes Clin Res. 2015;2(1):1-5.

29. Parlapally RP, Kumari KR, Jyothi SA. Serum Magnesium Levels in Type 2 Diabetes. Int J Sci c Study. 2016;4(5):176-9. 


\section{GRAPHICAL ABSTRACT}

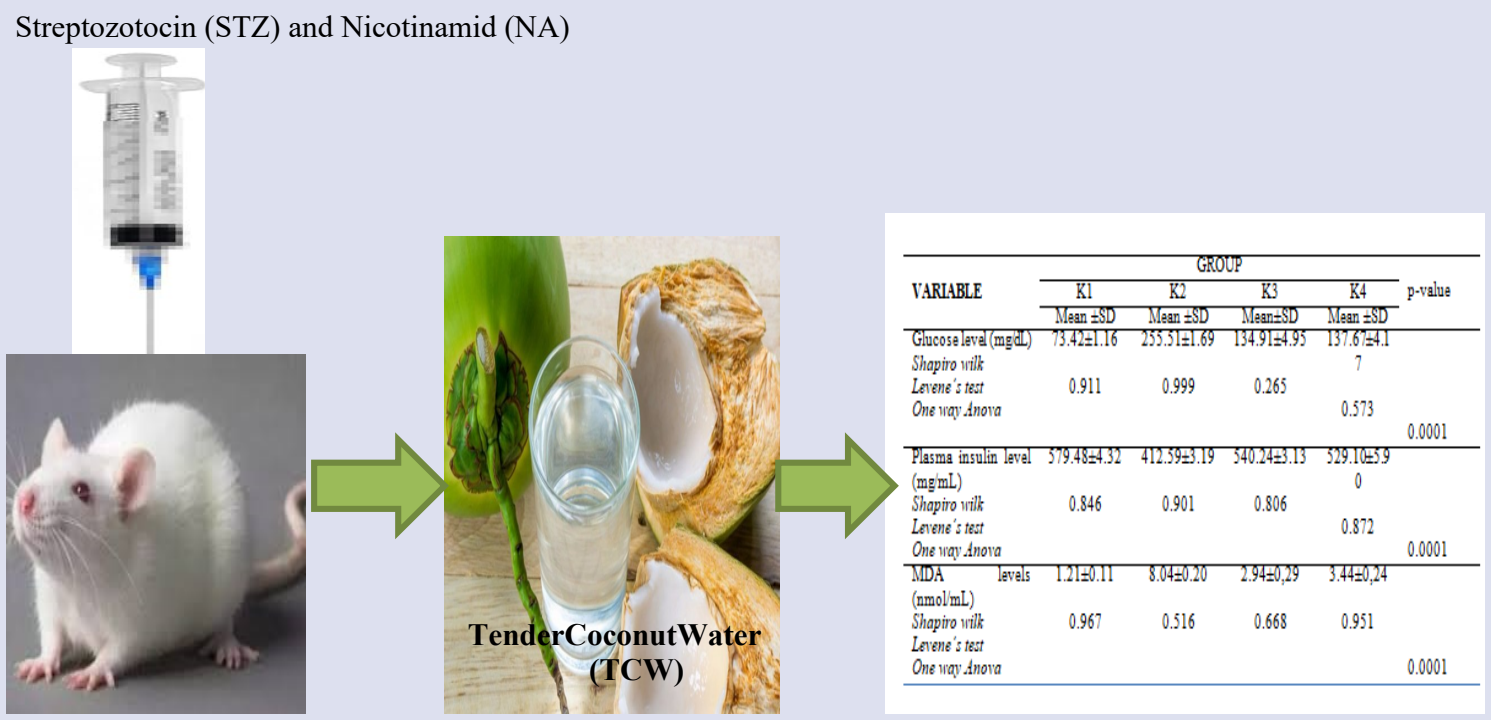

\section{Pregnant Rats}

\section{SUMMARY}

- Tender coconut water significantly descreased MDA Levels.

- Tender coconut water significantly descreased glucose Levels.

- Tender coconut water significantly increased plasma insulin Levels.

- Tender coconut water has inhibits the process of lipid peroxidation.

\section{ABOUT AUTHORS}

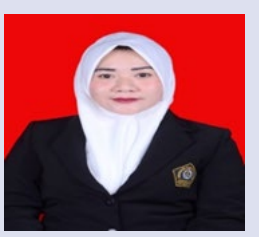

Friday Super Nova: Was a student at Program Master of Biomedical Science Faculty of Medicine Universitas Islam Sultan Agung, Semarang-Indonesia, where she graduated in Master of Biomedical. Her research focused on effect tender coconut water (TCW) on the On Insulin Plasma, Glucose and Malondialdehyde (MDA) Level In Pregnant Rats Type 2 Diabetes Mellitus.

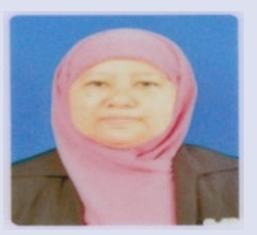

Siti Thomas Zulaikhah: Is an Associate Profesor at the Departement of Public Health, a lecturer and researcher at Program Master of Biomedical Science at Faculty of Medicine, Universitas Islam Sultan Agung Semarang-Indonesia. She is passionates in research on antioxidant especially Tender coconut water (TCW), prevention medicine and environment health.

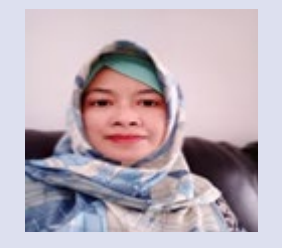

Atina Hussaana: Head of Research Development and Community Service Unit of Medical Faculty Universitas Islam Sultan Agung. Scope of her research is about Natural Products, and now she focusing research on Production, Formulation and Invitro Toxicity Testing of Nanoparticles from White Oyster Mushroom (Pleurotus ostreatus) Rich in Vitamin D.

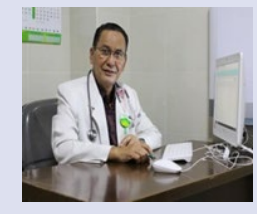

Shofa Chasani: A lecturer and researcher at Program Master of Biomedical Science at Faculty of Medicine, Universitas Islam Sultan Agung. He is also an internist at Sultan Agung Islamic Hospital.

Cite this article: Nova FS, Chasani S, Hussanna A, Zulaikhah ST. Tender Coconut Water Inhibits the Process of Lipid Peroxidation, Reduce Glucose Levels, and Increase Plasma Insulin in Pregnant Diabetic Rats. Pharmacog J. 2020;12(1):162-7. 